\title{
Proposal for a business plan for the improvement of MSMEs: Jarcieria Kiki's case
}

\author{
Propuesta de un plan de negocios para la mejora de las MIPyMES: Caso Jarcieria \\ Kiki's
}

PÉREZ-ALEJANDRE, Paola $†$ \& ANTONIO-VIDAÑA, Paula Rosalinda*

Universidad Tecnológica del Centro de Veracruz

ID $1^{\text {st }}$ Author: Paola, Pérez-Alejandre

ID $1^{\text {st }}$ Coauthor: Paula Rosalinda, Antonio-Vidaña / ORC ID: 0000-0002-1175-0611

DOI: $10.35429 / J A F .2020 .20 .7 .18 .26$

Received March 20, 2020; Accepted June 29, 2020

\begin{abstract}
Micro, medium and small companies, known by the acronym MIPyMES, have been gaining more and more importance both in their contribution to the economy, but in the same way they have been affected with great demands for their development, as is the case of the establishment KIKI'S dedicated to the sale of cleaning products and hardware which starts from the problem of not having the regulatory and strategic elements that allow it to be competitive. That is why this article aims to describe elements of a business plan that made it possible to strengthen the cleaning supplies company through the use of marketing strategies and techniques that helped increase its sales and competitiveness. The methodology used was quantitative and qualitative, marketing tools such as benchmarketing were used and surveys were applied, which had a favorable impact on the company, since in the face of the COVID-19 pandemic the management for sales was complicated, therefore they designed strategies considering the guidelines for the establishments.
\end{abstract}

MIPYME’s, Improvement, Business plan

\begin{abstract}
Resumen
Las micro, medianas y pequeñas empresas, conocidas con la sigla MIPyMES, han venido cobrando cada vez más importancia tanto en su contribución a la economía, pero de igual manera se han visto afectadas con grandes exigencias para su desarrollo, como es el caso del establecimiento KIKI'S dedicada a la venta de productos de limpieza y jarciería la cual parte de la problemática de no contar con los elementos normativos y estratégicos que le permitan ser competitiva. Es por ello que este artículo tiene como objetivo describir elementos de un plan de negocio que permitieron fortalecer a la empresa de artículos de limpieza mediante la utilización de estrategias y técnicas de marketing que coadyuvaron a incrementar sus ventas y su competitividad. La metodología utilizada fue cuantitativa y cualitativa, se utilizaron herraientas de marketing como el benchmarketing y se aplicaron encuestas, lo cual tuvo un impacto favorable a la empresa, ya que ante la pandemia COVID-19 se complicó la gestión para las ventas por lo que se diseñaron estrategias considerando los lineamientos para los establecimientos.
\end{abstract}

MIPYME's, Mejora, Plan de negocios

Citation: PÉREZ-ALEJANDRE, Paola \& ANTONIO-VIDAÑA, Paula Rosalinda. Proposal for a business plan for the improvement of MSMEs: Jarcieria Kiki’s case. Journal of Administration and Finance. 2020, 7-20: 18-26

\footnotetext{
*Correspondence to Author (email: paula.antonio@utcv.edu.mx)
}

$\uparrow$ Researcher contributing first author. 


\section{Introduction}

Today companies face a market with high demands such as prices, quality, variety, credit, location, the influence of external aspects such as major political and governmental changes in the world economy, the development of new technologies as well as pandemics. worldwide, have allowed the commercial area to be one of the main economic sectors where good planning is essential to know the needs of consumers and as such, make the most convenient decisions to meet the objectives and strategic goals, thanks to the support and joint work of all members of the company.

MIPyMES are micro, small and mediumsized companies, currently a SME can have difficulties particularly with its owners and collaborators, when developing both the business plan, the company's objectives, and the strategies to achieve the objectives with such exercises priorities that could have been raised, because the MSMEs and their collaborators have to be directly operating the business and cannot dedicate the time required to its strategic planning.

For this reason, it is advisable that companies adopt plans that include their mission, vision, resources, policies and values as an initial stage. under a meticulous analysis of several matrices that will help us detect the problems that the company faces such as the SWOT matrix, as well as an external analysis of the competition with the benchmarking tool.

In the same way, the MIPyMES establishments need to have strategies that help the establishment to promote and increase the commercial positioning to improve it and its segmentation of potential customers, as well as to support the organization of the company, increasing its profits and productivity, providing the tools for a good operation and organization of the company.

\section{Theoretical framework}

Micro-enterprises, known by the acronym MIPyMES, have been gaining more and more importance both in their contribution to the economy and to the well-being of their inhabitants, as large companies have gained share in the volume of production and the jobs generated. in the country.
Similarly, companies in these categories have been increasing their participation in the number of jobs, in production, in the Gross Domestic Product and in exports.

In 1998, according to the study carried out by the Inter-American Development Bank and the Center for Business Development, it was found that the main weakness of MSMEs is planning (Vargas, 2002).

For (Martín, 2011), I already mentioned that the entrepreneur is an innovator who creates new products, or already existing products and, in addition, is capable of implementing new production methods, reorganizing a company and creating new offers in the market; likewise, the entrepreneur is a generator of the economic growth of the entity where it will be located.

Definition of a business plan According to (Fleitman Jack, 2000), a business plan is defined as a key and fundamental instrument for success, which consists of a series of interrelated activities for the beginning or development of a company. As well as a guide that facilitates the creation or growth of a company.

According to (Schnaars, 1991) Marketing strategies, also known as Marketing Strategies, Marketing Strategies or Commercial Strategies, consist of actions that are carried out to achieve a certain objective related to marketing. The design of marketing strategies is one of the functions of marketing. In order to design strategies, first of all, we must analyze our target audience so that, based on this analysis, we can design strategies that are responsible for satisfying their needs or desires, and taking advantage of their characteristics or customs. But when designing marketing strategies, we must also take into account competition and other factors such as our capacity and our investment. The competitiveness for (Prieto \& Martínez, 2004) of the companies depends on many factors, among them: the installed technological capacity, the innovations carried out and, above all, the quality of the personnel in charge of the processes. The organization for Evans and Lindsay (2001) is a system and all the people who work within a system can contribute to their best, which will increase their pleasure in working, many factors within the system affect the individual performance of an employee for example: 
- $\quad$ The training received

- Information in the resources provided

- The leadership of supervisors and managers

- Work interruptions

- $\quad$ Administrative policies and practices

For the organization of an establishment, the layout tool can be used in the design area to explain the sketch, scheme or layout sketch of a specific design, in order that a client can more clearly observe an approximation of the final vision of what you could be buying, with the idea of selling you that option and completing the business, which will be executed according to the outline presented at that time after being approved (Raffino, 2019).

With this, an inventory can be carried out.According to Espinoza (2011), inventory control is a fundamental tool in modern administration, since it allows companies and organizations to know the existing quantities of products available for sale, in one place and determined time, as well as the applicable storage conditions in the industries.

To carry out an external and internal analysis according to Kotler, Bloom and Hayes (1997), Market Analysis "consists of systematically gathering, planning, analyzing and communicating the relevant data for the specific market situation faced by an organization".

Similarly, benchmarking is the process by which information is collected and new ideas are obtained, by comparing aspects of the company with the leaders or the strongest competitors in the market. Benchmarking is the activity of comparing one's own processes against the best known similar activity, so that challenging objectives are established, real challenges, but achievable, and a course of action is implemented that allows the organization to efficiently convert and stay as the best (L. Miren \& C. Ochoa, 2005).

\section{Methodology}

To carry out the project, 4 steps were established, which will allow, in addition to making a diagnosis, establishing the research design and the instruments to be used.
The first is market analysis, where a summary of consumer needs and the importance of competition close to the establishment will be shown.,

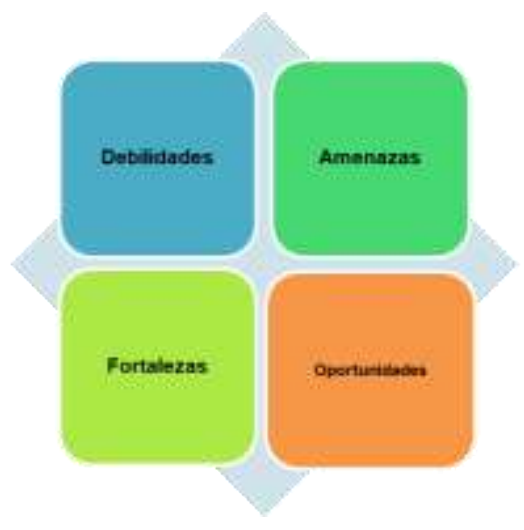

Figure 1 Step 1. Internal and external analysis Source: Self Made

The second Step is internal analysis, where it will be analyzed how the establishment is currently, considering the regulatory plan.

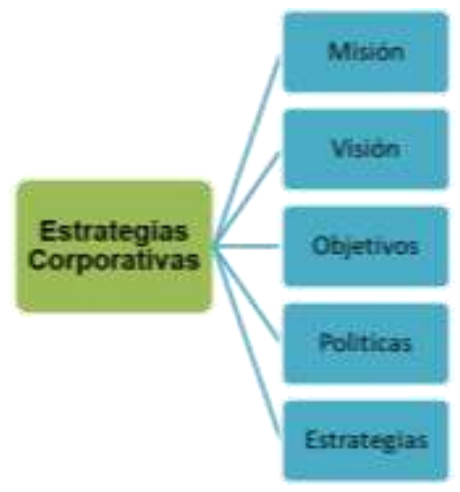

Figure 2 Step 2. Market analysis Source: Self Made

Complementing with the collection of information through qualitative research, it will be complemented with quantitative research when applying the survey instrument; the following illustration will show how to do it

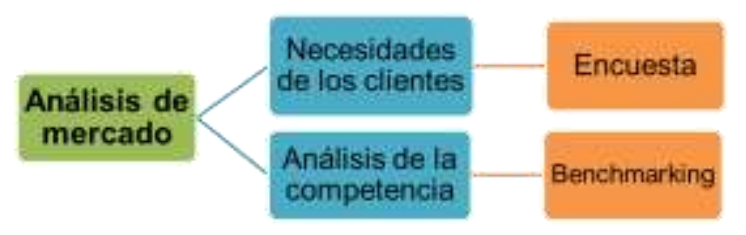

Figure 3 Step 3. Cooperative Strategies Source: Self Made 
For the third Step, as bases in the design of cooperative strategies, it is here where the philosophy of the company and strategies for it will be implemented, considering the diagnosis made, as well as the instruments to be used for the collection of information.

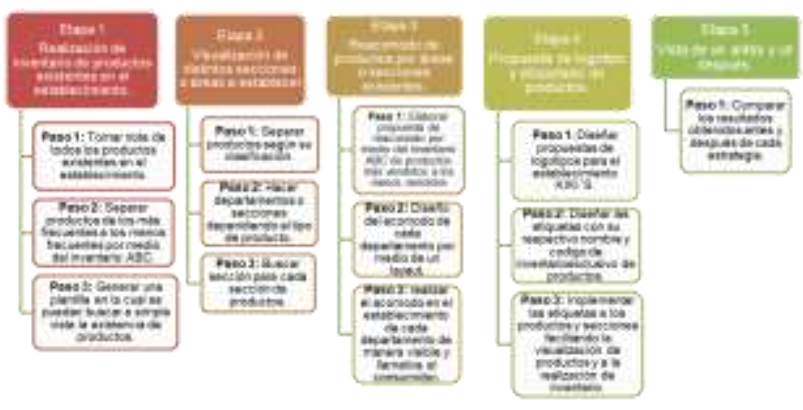

Figure 4 Step 4. Elaboration of objectives and strategies, indicators and goals

Source: Self Made

For the fourth Step the elaboration of objectives and strategies, indicators and goals, in the latter, taking into account the analysis of the product, focusing on the presentation, labeling and accommodation, in such a way that once carried out, strategies for improvement will be implemented. of said establishment.

According to the problems of the MIPyME company, case: KIKI'S dedicated to the sale of cleaning supplies and hardware does not have the regulatory and strategic elements that allow it to be competitive, in addition to the lack of a good organization at the establishment, Marketing strategies to help you increase your productivity. That is why strategies will be implemented to improve the establishment.

Due to the nature of the project, it is a qualitative and quantitative investigation, which seeks to analyze the problem through interpretation and understanding, evaluating and processing the results of said project. The type of research will be descriptive and exploratory since it tries to describe the reality of situations that are being addressed and that it is intended to analyze and seeks to explain the causes that originated the analyzed situation.

\section{Results and Analysis}

Next, the results obtained in these steps will be shown. For the first Step, an analysis was carried out through a SWOT matrix in which it showed us how the company is doing internally and externally, as shown in Figure 5.

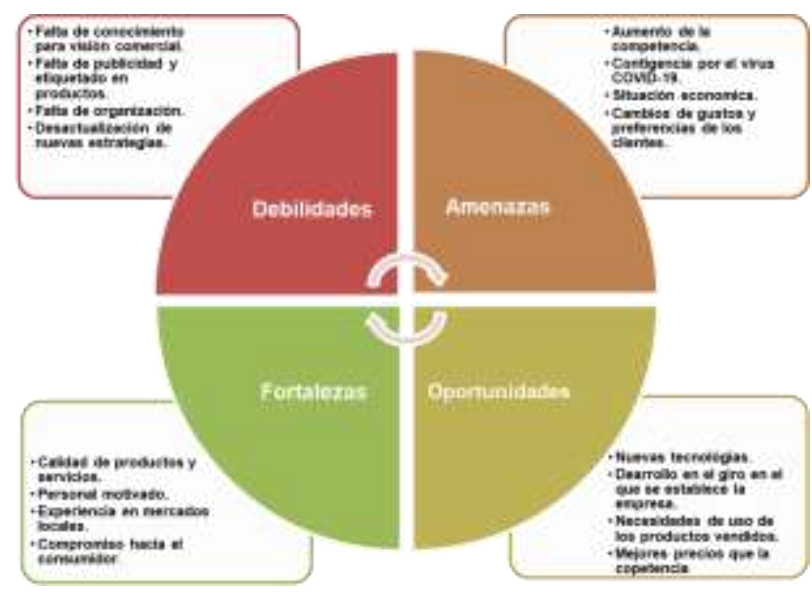

Figure 5 Análisis SWOT carried out to the company to detect the problem Source: Self Made

When conducting the analysis, it was detected that they lack knowledge about strategies both for the improvement of the establishment and for its sales, since they are entrepreneurs who are not pending new trends such as the use of technology, and innovations that allow them to give more competitiveness, control, organization and can give you a guideline to be a better establishment than that of your close competitions.

In the same way, it can be observed that, being small establishments, they are more likely to suffer economic situations since the threats that the establishment has goes from increased competition to the economic situation that the country is going through, since at present A difficult situation is being experienced due to the PANDEMIC suffered by COVID-19, which affected the MSMEs as it was for the KIKI'S establishment.

With this analysis, it was possible to realize the situation the establishment is going through and where strategies had to be established to increase its productivity and improve towards the consumer. After this in the same way, a survey was carried out, this to know the consumer's point of view and the degree of positioning in which the establishment was within its locality.

Given the pandemic and the restrictions given for the development of activities in the field, surveys were applied at the location of the company considering the competition it had in the neighborhood where it is located. 
This survey has 6 items, each of them in turn establishes 4 response options, which were applied near the KIKI'S establishment in the Santa Rosalia neighborhood of the municipality of Córdoba, Veracruz, where they were applied to 15 people and amas From home. The results of the survey can be seen that the 15 people who were applied acquire cleaning products since, due to the contingency that is being experienced, more cleaning is carried out in their homes, thereby determining the demand for the product.

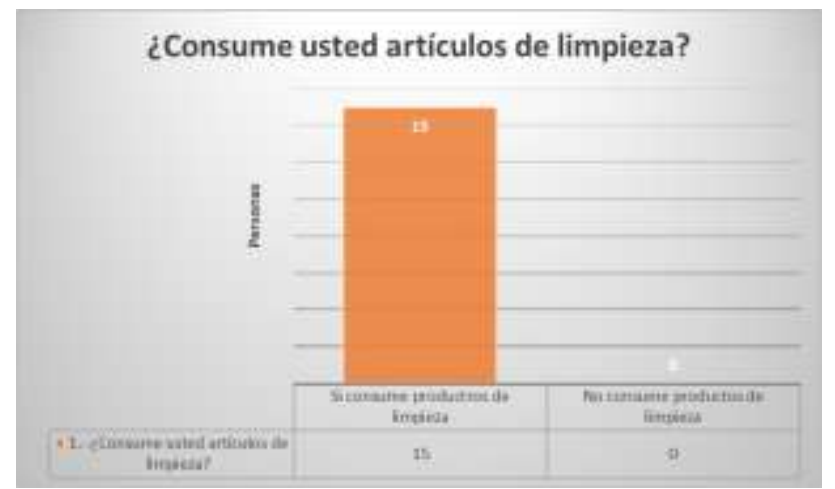

Graphic 1 Presentation of the demand for cleaning products in housewives

It can also be noted with the frequency that they consume these products, which most buy with a weekly and biweekly frequency than daily since it makes them more economical to make the purchase in this way, the place of their preference for the majority of consumers in the colony of Santa Rosalia prefer to make their purchase in establishments such as groceries and hardware stores, since they comment that it is a little cheaper and the quality of the product is usually better, like everything else, most usually buy cleaning products by the liter, this is more easy for consumers and save a little more.

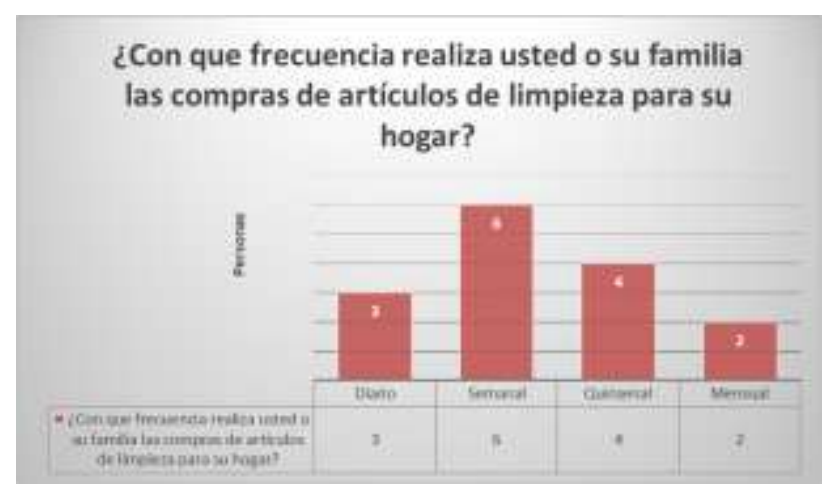

Graphic 2 Frequency with which cleaning products are purchased by housewives
The impact that the KIKI'S establishment has in the Santa Rosalia neighborhood of the 15 people who were surveyed, only 10 knew about the establishment, this is because it does not have much publicity and its location is not known exactly. It also showed what consumers were looking for to purchase cleaning products and obtained Quality and variety of presentations in products, the arrangement and visibility of products, as well as availability of prices is what consumers look for in products and at establishment to make a purchase.

For the second Step, a market analysis was carried out in which the benchmarking tool was used in order to compare the KIKI's establishment with its direct competencies. in which the indicators are written where the total score of each establishment, therefore, we can see that the KIKI'S establishment has 2 indicators in which it is not very competent, they are design and point of sale with a 1.26 and complementary services with a 0.24 . Where the variables where it is intended to improve or innovate is the establishment are:

\section{- $\quad$ Product organization.}

- $\quad$ Product labeling, in which a logo, slogan and representative labels will be provided to the establishment.

The results obtained in the previous analyzes can be shown, it is intended to propose strategies for their improvement, this to help the establishment to be more competitive and highlight its close competition.

\section{Proposal}

After the results obtained, strategies were proposed, with which the purpose is for the establishment to have an order and adequate organization of the products in the establishment, a logo with which it represents the establishment.

A label showing the name, logo and address of the establishment, as well as the product name, quantity code and the precautionary measures to be followed. These proposed strategies will be shown below. 


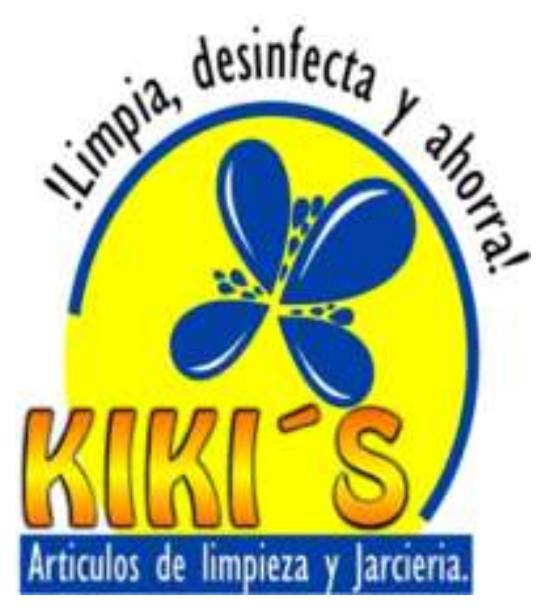

Figure 6 Logo design for the KIKI's establishment

First, it was carried out with a count of the products that the KIKI's establishment has in which, due to the contingency due to the COVID-19 pandemic, it was not possible to carry out an in-depth count of products in stock, therefore only They took fundamental products that said establishment has, as well as an estimate of their price, existence and investment.

Then an inventory was carried out by the ABC method in which a count of the products was analyzed, their code, name, demand, unit price and investment, to later make the accumulated investment equal in percentage and the area in which it belongs (zone A zone B and zone C).

Taking this into account, a template was made where all existing products can be emptied for a better inventory which will have: product code, description, initial stocks, inputs, outputs and stock (said template will be attached in the mail). Then it began with the visualization of different sections or areas to be established, in which it was established to separate the products according to their classification, this means making sections of products from the same range so that after, they are classified depending on the demand for These same.

This corresponds to making different minidepartments in the establishment in such a way that it is more visible or easier to find the products that the establishment has for sale, taking into account this, it is proposed to carry out a design to rearrange the products by existing areas or sections, which It will be supported by the ABC inventory, this will allow us to prepare a proposal to rearrange the best-selling products to the least attracted or least needed for the consumer, in this way attracting the customer's attention when arriving at the establishment.
This will help to have an order in the products and to display it.

After the realization of the proposal of the rearrangement proposal for the establishment and already authorized by the owner of the same, we proceed to carry out the accommodation of each department in a visible and striking way to the consumer in the establishment in a physical way, with the aim of show all the ranges of products that are available in the establishment as well as the order that you want to obtain in it.

Where it was decided to design a layout of a rearrangement in the establishment, showing the different areas distributed in the establishment, following the ABC classification.

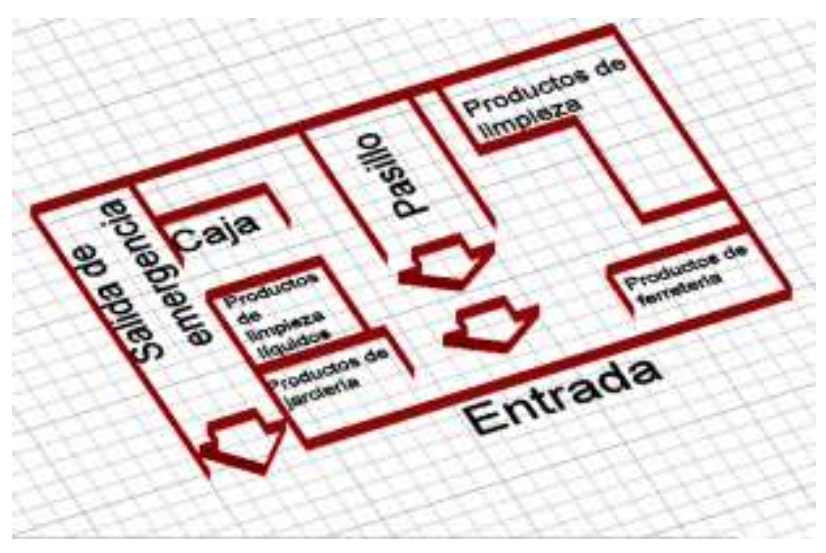

Figure 7 Proposal design for product arrangement

After the proposal of the design of rearrangement of the products, it is proposed to create a logo and labeling of products in which it was taken into account for its preparation to implement a slogan, colors alluding to the establishment and the name of the establishment. Having already established the logo that will represent the establishment, the product label was made where the aforementioned logo will be placed, address and name of the establishment, as well as product, code and net weight according to Figure 8 .

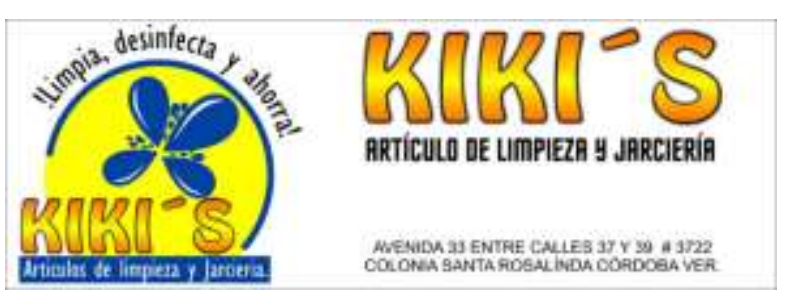

Figure 8 Label design for KIKI's company products 


\section{Conclusion}

After the completion of this study, the following conclusions could be reached: The KIKI'S company dedicated to the sale of cleaning supplies and hardware has experienced not having the regulatory and strategic elements that allow it to be competitive, lacking help to identify the requirements on which every company is supported for its proper functioning in terms of marketing and control strategies.

Taking into account the results of the analyzes carried out, the establishment lacks knowledge about strategies both for the improvement of the establishment and for its sales, since they are entrepreneurs who are not pending new trends such as technology, and innovations that allow them to give more competitiveness, control, organization and can give it a guideline to be a better establishment than that of its nearby competencies, in the same way it was observed that among its competencies the establishment did not have a place according to the business which It made it look unattractive to the consumer, likewise the products did not have any characteristics of realization that could be identified as coming from the KIKI's establishment.

That is why the purpose of this research is the proposed strategies in which the establishment will be improved, innovating it before new marketing techniques such as product labeling, as well as the rearrangement and organization of products. Thus benefiting the establishment with proposals and providing them with both regulatory and strategic elements, allowing them to increase their productivity, competitiveness, making them more visible to consumers and at the same time increasing sales in the establishment.

\section{References}

Andrews, K. R. (2009). The Concept of Corporate Strategy. New London: Concept of Corporate Strategy. Homewood III. .

Arias, F. (1990). Administración de los recursos humanos. En F. Arias, Administración de los recursos humanos (pág. Cuarta edición). Trillas.

Armijo, M. (2009). Planificación Estratégica en organizaciones públicas. INDETEC-ILPESCEPAL.
Arrieta Posada, J. G. (2011). Aspectos a considerar para una buena gestión en los almacenes. En J. G. Arrieta Posada, Layout del centro de distribución (pág. Pag. 91). Journal of Economics, Finance and Administrative Science.

Badia, A. y. (1999). Técnicas para la gestión de la calidad: control de la calidad-ISO 9000, gestión por procesos, Diagramas de proceso, gestión de la calidad total, benchmarking, reingeniería, Tecnos. Madril.

Ballou, R. (2004). Administración de la cadena de suministro. México: Pearson Educación.

Boda, T. (2015). The role of innovative entreprencurs in rural development. Usa: European Scientific Journal.

Castorena, O. H. (2017). Proveedores y modelos de gestión en la cadena de suministro: Pymes manufactureras de Aguascalientes. En O. H. Castorena, Proveedores y modelos de gestión en la cadena de suministro: Pymes manufactureras de Aguascalientes (pág. Vol.7 \#1). FACCEA.

Castro, C. V. (2011). Clasificación ABC Multicriterio: tipos de criterios y efectos en la asignación de pesos. En C. V. Castro, Clasificación ABC Multicriterio: tipos de criterios y efectos en la asignación de pesos. (págs. Pag. 163-170). Iteckne.

Ducker, P. F. (1991). Tradución al español de The new productivity challege. En P. F. Ducker, Tradución al español de The new productivity challege (págs. Pag. 69 -79). Harvard Business Review.

Económica, E. (2017). Enciclopedia Económica : https://enciclopediaeconomica.com/mision/).

Espinoza, O. (2011). La administración eficiente de los inventarios. En O. Espinoza, Control de inventarios (pág. primera edición).

Evans, J. Y. (2001). Administración y control de la calidad. En J. Y. Evans, Administración y control de la calidad (pág. Cuarta edición). Internacional Thomson Editores S.A. de C.V.

F. Robert Jacobs, N. J. (2009). ADMINISTRACIÓN DE OPERACIONES 12ED. En N. J. F. Robert Jacobs, ADMINISTRACIÓN DE OPERACIONES 12ED (pág. Pág. 374). McGraw-Hill.

PÉREZ-ALEJANDRE, Paola \& ANTONIO-VIDAÑA, Paula Rosalinda Proposal for a business plan for the improvement of MSMEs: Jarcieria Kiki's case. Journal of Administration and Finance. 2020 
Fleitman Jack, N. E. (2000). negocios exitosos. En p. I. García-Pastor, Plan de Negocio. McGraw Hill.

Fuentes, F. (2018). Productividad: El Eslabón Perdido del crecimiento . En F. Fuentes, Productividad: El Eslabón Perdido del crecimiento . (págs. 4-5). Observatorio Económico .

Geoffrey, R. (2003). Principios de Marketing. En R. Geoffrey, Principios de Marketing (pág. Pag. 120). Segunda edición, Thomson Editores Sapin.

González, A. (11 de Enero de 2018). emprendepyme.net. Obtenido de emprendepyme.net:

https://www.emprendepyme.net/organigramafuncional.html

J., B. (1985). Manual de Administración para la Pequeña y Mediana Empresa en México. En B. J., Manual de Administración para la Pequeña y Mediana Empresa en México. México: Osar.

Jack, F. (2000). Negocios Exitosos. En F. Jack, Negocios Exitosos (pág. Pág. 246). México: Mc Graw Hill.

Josefa Eugenia Blasco Mira, J. A. (2007). Metodologías de investigación en las ciencias de la actividad física y el deporte: ampliando horizontes. bitstream.

Josefa Eugenia Blasco Mira, J. A. (2007). Metodologías de investigación en las ciencias de la actividad física y el deporte: ampliando horizontes. bitstream.

Kearns, D. (2012). Benchmarking. EAE .

Kotler Philip, B. P. (2004). El Marketing de Servicios Profesionales. En B. P. Kotler Philip, El Marketing de Servicios Profesionales (pág. Pág. 98.). España: Ediciones Paidós Ibérica S.A.

Kotler, P. (2001). Dirección de Mercadotecnia. En P. Kotler, Dirección de Mercadotecnia (pág. pag.7). Pearson Educación.

Laburu, M. G. (2005). Una revisión teórica de la herramienta de benchmarking. Revista de Dirección y Administración de Empresas. Enpresen Zuzendaritza eta Administraziorako Aldizkaria. .
Manene, L. M. (2014). BENCHMARKING: HISTORIAL, DEFINICIONES, APLICACIONES Y BENEFICIOS. España: Actualidad empresa.

Martín, M. E. (2011). Perfil emprendedor de los gerentes de las empresas lácteas del Municipio Colón del estado Zulia. Revista Visión Gerencial, pag.120-135 .

Martínez, M. M.-L. (2005). Clasificación toxicológica, envasado y etiquetado de productos químicos. Pamplona, España: Asociación Española de Toxicología.

Melania Sofia Fernández León, E. C. (2010). Elavoración de un plan estratégico para la empresa Tecni Ferreteria Ricauter . méxico: Universidad Facultad de las ciencias económicas y administrativas.

Mintzberg Henry, Q. J. (1993). El proceso estratégico, . México: Hall Inc.

Mulcahy, D. (1994). Warehouse Distribution and Operations Handbook. New York: McGrawHill.

Naresh, M. K. (1997). Investigación de Mercados Un Enfoque Practico. En M. K. Naresh, Investigación de Mercados Un Enfoque Practico (págs. rentice-Hall Hispanoamericana). Segunda Edición: rentice-Hall Hispanoamericana.

Naresh, M. K. (1997). Investigación de Mercados Un Enfoque Practico. En M. K. Naresh, Investigación de Mercados Un Enfoque Practico (pág. Págs. 90 al 92.). Prentice-Hall Hispanoamericana.

Navarrete, D. O. (14 de septiembre de 2017). universia.

https://noticias.universia.cr/educacion/noticia/2 017/09/04/1155475/tipos-investigaciondescriptiva-exploratoria-explicativa.html

Nichol, F. (1998). Estarategia Corporativa. Estados Unidos.

Prieto, A., \& Martínez, M. (2004). Sistemas de información en las organizaciones: Una alternativa para mejorar la productividad gerencial en las pequeñas y medianas empresas. Maracaibo, Venezuela: Revistas de ciencia sociales . 
Pupo, G. A. (11 de Marzo de 2002). Gestiopolis. https://www.gestiopolis.com/un-concepto-deestrategia/

Raffino, M. E. (29 de noviembre de 2019). concepto.de. Obtenido de concepto.de: https://concepto.de/layout/

Raffino., M. E. (12 de febrero de 2020). Concepto de. 19 de junio de 2020, de concepto de: https://concepto.de/politicas-de-unaempresa/

Richard, M. (1982). Distribución en Planta. En M. Richard, Distribución en Planta (pág. cuarta edición). Barcelona, España: Distribución en Planta.

Rivera, A. (07 de agosto de 2015). Significados.com. Obtenido de Significados.com:

https://www.significados.com/layout/

Roberto Carro Paz, D. G. (2013). Productividad y Competitividad. En D. G. Roberto Carro Paz, Concepto amplio de la competitividad (pág. Pag. 01). dministración de las Operaciones universidad Nacional de mar del Plata.

Rodrígo Renovato, J. C. (2014). Perfil de los empresarios y la relación con la cooperación interrempresarial en empresas del estado de Aguascalientes. Aguascalientes: Tesis en Maestro en Ciencias en Administración. Instituto Tecnológico de Aguascalientes.

Rubén Macías Acosta, A. L. (2019). Análisis de la cadena de suministro por clasificación $A B C$ : el caso de una empresa mexicana. México: Revista Academia \& Negocios.

Sánchez Hernández, G. (2009). Cómo hacer un plan de negocios. México: Entrepreneur Mexico.

Schnaars, S. P. (1991). Estrategias de marketing. Madrid, España: Ediciones Díaz de Santos.

Silva, A. S. (2013). Metodología cuantitativa: abordaje desde la complementariedad en ciencias sociales. En A. S. Silva, Metodología cuantitativa: abordaje desde la complementariedad en ciencias sociales (pág. Pag. 28). San José, Costa Rica: Revista de Ciencias Sociales.
Thompson, I. (abril de 2019). promonegocios.net.

https://www.promonegocios.net/mercado/estudi os-mercados.html

Vargas, A. (2002). Modelo para la elaboración de un plan de negocios para las empresas pequeñas y medianas. En A. Vargas, Modelo para la elaboración de un plan de negocios para las empresas pequeñas y medianas (págs. 93108). Estudios Gerenciales.

Vermorel, J. (Marzo de 2020). lokad. Obtenido de lokad: https://www.lokad.com/es/definicionanalisis-abc-

(inventario)\#: :text=El\%20an\%C3\%A1lisis\%2 0ABC $\% 20$ es $\% 20$ un $\% 20 \mathrm{~m} \% \mathrm{C} 3 \%$ A 9 todo $\% 20 \mathrm{de}$ $\% 20$ categorizaci\%C3\%B3n\%20de\%20inventar io,m\%C3\%A1s\%20se\%20venden\%20y\%20con sumen.

Villarán, K. W. (2009). Plan de negocios. En K. W. Villarán, Características esenciales de un empresario exitoso de una Micro o Pequeña empresa (pág. 17). Perú: USAID.

Villarán, K. W. (2009). Plan de Negocios. Perú: industrial Data. 